\title{
PENYULUHAN PENGETAHUAN KUALITAS BIBIT SAPI PERAH PADA KELOMPOK TERNAK BINAAN BALAI PERBIBITAN DAN PENGEMBANGAN INSEMINASI BUATAN TERNAK SAPI PERAH (BPPIBTSP) BUNIKASIH CIANJUR (Counseling Knowledge of The Quality of Dairy Cows Breeds In The BPPIBTSP, Bunikasih Cianjur)
}

\author{
Raden Febrianto Christi*, Heni Indrijani*, Didin S. Tasripin* \\ *Fakultas Peternakan Universitas Padjadjaran Sumedang Jawa Barat \\ e-mail: raden.febrianto@unpad.ac.id
}

\begin{abstract}
ABSTRAK
Sapi perah merupakan ternak ruminansia besar yang menghasilkan produk berupa susu.

Produktivitas suatu ternak baik buruknya dilihat dari kualitas bibit yang dihasilkan. Pengabdian ini bertujuan untuk meningkatkan pengetahuan peternak dalam upaya menentukan kualitas bibit sapi perah yang baik. Tahapan pengabdian dilakukan melalui survey lapangan, studi literatur, penyuluhan dan demonstrasi melalui 2 metode yaitu perangkat media (tidak langsung) dan aplikatif terhadap ternak (langsung). Penyuluhan telah dilakukan pada kelompok ternak sapi perah binaan Balai Perbibitan dan Pengembangan Inseminasi Buatan Ternak Sapi Perah (BPPIBTSP) Bunikasih Kecamatan Warung kondang Kabupaten Cianjur yang dihadiri oleh 50 peserta dari berbagai kalangan umur kemudian dilanjutkan dengan demonstrasi. Hasil menunjukkan bahwa penyuluhan dapat meningkatkan pengetahuan tentang cara mengetahui kualitas bibit yang baik hal ini terlihat dari jawaban kuisioner pre test dan post test. Kesimpulan bahwa penyuluhan dapat meningkatkan pengetahuan kualitas bibit sapi perah di kelompok peternak binaan BPPIBTSP Bunikasih sehingga mampu menentukan kualitas bibit unggul yang baik melalui karakteristik dari ternaknya.
\end{abstract}

Kata kunci : kualitas bibit sapi perah, kelompok ternak, BPPIBTSP, Cianjur 


\section{PENDAHULUAN}

Indonesia sampai saat ini untuk konsumsi susu belum dapat dipenuhi melalui produksi dalam negeri sehingga harus melakukan proses impor. Akibatnya terjadi laju perkembangan agribisnis sapi perah yang lamban dan menyebabkan beberapa peternak beralih profesi atau beternak dengan komoditas yang lain bahkam sampai terjadi gulung tikar. Angka kebutuhan susu secara nasional mencapai 4,5 juta liter/hari, tetapi produksi susu saat ini baru memenuhi 30\% dari kebutuhan manusia dan selebihnya 70\% di impor dari luar negeri (Yani dkk., 2006).

Proses importasi susu dari luar sebetulnya bisa ditekan secara perlahan-lahan asalkan didukung dengan adanya faktor internal dan eksternal. Faktor internal meliputi faktor genetik yang baik, sedangkan eksternal meliputi manajemen pemeliharaan. Tetua yang baik maka akan dihasilkan calon bibit yang baik pula sehingga produktivitasnya baik dalam hal ini terjadi peningkatan produksi dan kualitas suus. Sedangkan faktor manajemen pemeliharaan yang baik meliputi upaya pencegahan penyakit (kesehatan), pemberian pakan, dan sanitasi kandang adalah perangkat dalam mendukung bibit menjadi.produktivitasnya meningkat pula. Faktor lingkungan memegang peranan penting terhadap proses perkembangan fisiologis tubuh sapi perah, sehingga pada gilirannya akan mempengaruhi kapasitas produksi susu. Faktor iklim masih dapat diatasi dan tidak banyak berpengaruh apabila sapi perah tersebut diberi pakan yang berkualitas tinggi sehingga dapat berproduksi sesuai dengan kemampuannya (Siregar, 1992).

Produksi susu dapat ditingkatkan dengan adanya manajemen breeding yang baik serta dalam usaha peternakan sapi perah, salah satu usaha yang dilakukan adalah dengan mengetahui bibit unggul dalam menunjang produktivitas. Bibit merupakan pilar yang sangat penting bagi peternak atau orang yang baru dalam berwirausaha khususnya di bidang sapi perah. Pemilihan bibit harus dilakukan dengan cermat dalam penilaian kualitatif ternak sapi perah seperti bagian-bagian tubuh seperti kepala, bahu, punggung, bokong, pangkal paha, kaki, pundak, kapasitas tubuh, dan ambing. Bibit yang baik akan menghasilkan produk yang baik pula. Pemilihan bibit dapat dilakukan melalui pencatatan atau berdasarkan tampilan bentuk tubuh. Apabila dalam suatu peternakan tidak memiliki pencatatan maka pemilihan sapi perah dilakukan berdasarkan tampilan 
bentuk tubuh. Oleh karena itu penting, untuk pengenalan bagian tubuh dan konformasi tubuh yang ideal.

\section{MATERI DAN METODE PELAKSANAAN}

Penyuluhan tentang pengetahuan kualitas bibit sapi perah telah dilaksanakan bulan oktobernovember di Kelompok Ternak Binaan Balai Perbibitan dan Pengembangan Inseminasi Buatan Ternak Sapi Perah (BPPIBTSP) Bunikasih Kecamatan Warung Kondang, Kabupaten Cianjur. Kegiatan penyuluhan terhadap masyarakat melalui tahapan-tahapan proses yang meliputi Tahapan meliputi: 1. Persiapan: Persiapan dengan melaksanakan survey terhadap lapangan yang akan dijadikan sebagai tempat untuk melaksanakan kegiatan penyuluhan serta menentukan jadwal kegiatan dengan ketua kelompok dan pegawai BPPIBTSP. Kemudian menggali informasi dengan peternak sapi perah tentang permasalahan kualitas bibit sapi perah yang nantinya akan diberikan solusi permasalahannya dan dipadukan dengan sumber kepustakaan yang ada. 2 . Penyuluhan : Penyuluhan dilakukan dengan gabungan dari beberapa kelompok peternak sapi perah sehingga berjumlah 50 peserta. Peserta merupakan peternak sapi perah kelompok binaan BPPIBTSP Bunikasih diharuskan mengisi kuisioner yang berisi materi sebelum dan sesudah (Pre test dan Post Test). Tahapan ceramah dilakukan dari pemateri penyuluhan dan disampaikan kepada peserta yang hadir. Cara diskusi yang dilakukan adalah dengan metode FGD (Forum Group Discussion) dimana setiap peserta diperbolehkan untuk bertanya kepada narasumber atau pemateri terkait dengan materi yang telah disampaikan dan memecahkan permasalahanpermasalahan yang terjadi dilapangan.3. Demonstrasi: langsung menerapkan atau mengaplikasikan pada ternak sapi perah tentang kualitas bibit sapi perah yang baik.

\section{HASIL DAN PEMBAHASAN}

Penyuluhan tentang pengetahuan bibit sapi perah yang dilakukan di kelompok ternak binaan BPPIBTSP Bunikasih dihadiri oleh peserta sebanyak 50 orang peternak. Kegiatan diawali dengan perkenalan sebagai narasumber yang akan memberikan penyuluhan serta melakukan demonstrasi kepada peserta. Penyuluhan yang diberikan kepada peserta berupa materi mengenai kualitas ternak sapi perah. Breeding atau bibit dalam suatu peternakan sangat penting untuk diperhatikan 
hal ini karena berpengaruh terhadap produktivitas ternak selanjutnya. Ternak yang unggul dapat meningkatkan performa seperti peningkatan produksi dan kualitas susu bahkan sampai peningkatan kinerja reproduksi.

Sapi Perah Friesien Holstein (FH) merupakan jenis ternak perah dengan produksi susu tinggi dengan kadar lemak rendah yaitu 6800-17000 kg per masa laktasi (Makin, 2011). Potensi sapi perah keturunan FH dapat dimaksimumkan dengan perbaikan mutu bibit, diantaranya mengidentifikasi berbagai sifat kualitatif dan kuantitatif sehingga diperoleh bibit yang berkualitas. Sifat kualitatif seperti karakteristik sapi perah FH merupakan salah satu hal yang diperhitungkan dalam pemilihan calon bibit. Sifat kuantiatif seperti ukuran tubuh erat kaitannya dengan produksi dan dapat dijadikan acuan untuk memilih calon bibit selain dari catatan produksi susu (Martojo, 1992). Adanya pemaparan tersebut terkadang masih banyak peternak yang minim pengetahuan akan penentuan kualitas bibit sapi perah unggul yang belum paham dan mengerti. Penentuan bibit kualitas sapi perah yang baik belum begitu banyak diketahui oleh peternak karena pusat perhatian hanya fokus kepada produksi yang dihasilkan. Penentuan genetik mengenai bibit yang baik sering dilaksanakan oleh instansi terkait seperti yang dilakukan balaibalai inseminasi buatan. Pelaksanaan tersebut jarang berlanjut karena ada suatu kelompok ternak belum menerapkannya secara baik dan benar. Dengan melihat permasalahan yang ada penting sekali kepada setiap peternak untuk diberikan pengetahuan mengenai kualitas bibit sapi perah yang baik.

Penampilan umum bibit sapi yang baik meliputi mata lebar, moncong pendek, kepala halus, kepala tegak, ambing tumbuh baik, posisi simetris (Bugiwati, 2007). Bagian kepala harus atraktif yaitu halus, lubang hidung dan mulut besar. Bahu harus kuat tetapi tidak kasar, berbahu menyayap. Punggung lurus mengindikasikan kokoh serta kuat dan diharapkan lurus (Sugeng, 1993). Bokong dan pangkal paha harus panjang dan kuat karena keterlibatan dalam menopang ambing sapi perah. Kaki harus lurus dan kuat serta lebar untuk menyangga ambing yang lebih besar. Pundak harus tajam melebihi bagian atas punggung lemak tubuh sedikit. Ambing yang baik cukup besarm bentuk memanjang dari depan ke belakang. Semakin ke belakang semakin baik kemudian jumlah putting sebanyak 4 kuartir (Makin, 2011). 
Kegiatan penyuluhan ini dilaksanakan pemaparan materi dengan baik dan benar bahkan ketika penyampaian peserta langsung antusias dalam mengajukan permasalahan-permasalahan yang sering ditemukan dilapangan dalam bentuk pertanyaan. Oleh karena itu, dengan diberikannya penyuluhan mengenai penerapan pengetahun kualitas bibit sapi perah membuat peternak semakin tahu dan dapat mengatasi permasalahan tersebut.

\section{KESIMPULAN}

Penyuluhan kegiatan pengabdian kepada masyarakat tentang peningkatan pengetahuan kualitas bibit pada ternak sapi perah di Kelompok Binaan Balai Perbibitan dan Pengembangan Inseminasi Buatan Ternak Sapi Perah (BPPIBTSP) Bunikasih Kecamatan Warung Kondang, Kabupaten Cianjur terlaksana dengan baik, hal tersebut terbukti dari antusias atau keaktifan dari setiap peserta serta melaksanakan kegiatan diskusi dengan aktif. Selain itu peserta dapat bertambah pengetahuannya tentang kualitas bibit ternak sapi perah.

\section{UCAPAN TERIMA KASIH}

Penulis ucapkan terima kasih yang sebesar-sebesar kepada Universitas Padjadjaran yang telah memberikan hibah Riset Kompetensi Dosen Unpad (RKDU) 2019 serta ketua kelompok ternak sapi perah dan kepala balai di BPPIBTSP Bunikasih Kecamatan Warung kondang, Kabupaten Cianjur yang telah memfasilitasi dalam kegiatan pengabdian ini sehingga dapat terlaksana dengan baik. Selain itu, ucapan terima kasih pula kepada seluruh masyarakat yang sudah berpartisipasi dalam menyukseskan kegiatan ini.

\section{DAFTAR PUSTAKA}

Bugiwati, S. R. A. 2007. Pertumbuhan dimensi tubuh pedet jantan sapi Bali di Kabupaten Bone dan Barru Sulawesi Selatan. Jurnal Sains dan Teknologi 7:103-108.

Makin, M. 2011. Tatalaksana Peternakan Sapi Perah. Graha Ilmu, Yogyakarta. hlm 9. 
Martojo H. 1992. Peningkatan Mutu Genetik Ternak. Departemen Pendidikan dan Kebudayaan. Direktorat Jenderal Pendidikan Tinggi. Pusat Antar Universitas Bioteknologi IPB. Bogor.

Sugeng. 1993. Hubungan Bobot Badan dengan Lingkar Dada, Tinggi Pundak, dan Panjang Badan Sapi Perah. Buletin Peternakan. Jakarta.

Siregar, S. 1992. Jenis Teknik Pemeliharaan dan Analisis Usaha Sapi Perah. Penebar Swadaya, Jakarta.

Yani, A. dan B. P. Purwanto. 2006. Pengaruh Iklim Mikro terhadap Respons Fisiologis Sapi Peranakan Fries Holland dan Modifikasi Lingkungan untuk Meningkatkan Produktivitasnya. Media Peternakan. 